\title{
HRM Practices-Engagement-Performance Relationships: A Conceptual Framework for RMG Sector in Developing Economy
}

\author{
Shaheen Ahmed \\ PhD student, School of Business Management, Universiti Utara Malaysia, Malaysia \\ E-mail: shaheenmahmed@yahoo.com
}

Dr. Fais Bin Ahmad

Associate Professor and Head of the Department, School of Business Management, Universiti Utara Malaysia, Malaysia

E-mail: fais@uum.edu.my

\section{Dr. Mohd Hasanur Raihan Joarder}

Visiting Senior Lecturer, School of Business Management, Universiti Utara Malaysia, Malaysia E-mail: hasanur@uum.edu.my

Doi:10.5901/mjss.2016.v7n4p

Abstract

The relationships among the HRM practices, employee engagement and performance have received a significant attention all over the world. This study has attempted to develop a conceptual framework using the role of employee engagement as mediator in HRM practices and performance relationship in the readymade garment industry in Bangladesh. The proposed framework portrayed that HRM practices have positive influence on both employee engagement and performance. Similarly, employee engagement also has a positive influence on performance. The policy makers and other HR consultants and practitioners certainly can improve the employee performance by using this model.

Keywords: HRM practices, engagement, employee performance, readymade garment industry.

\section{Introduction}

Employees' performance ensures the survival as well as growth of the organizations (Emami et al., 2013). Some argued that HRM practices should be treated as the core element for organizations success by means of improved employee performance (Al-Homayan, Shamsuddin and Islam, 2013). According to Karatepe (2013) HRM practices have positive and direct relationship with employees' work engagement, especially in labour intensive organization. A significant number of studies have been conducted on employees' performance in the developed economy, but very limited in the context of developing countries, for example Bangladesh in particular (Mahmood, 2004). Due to high labour intensiveness in nature, the HRM practices in the readymade garment (RMG) industry carry an extra importance (Huda et al. 2007).

HRM practices have been noted as an indicator of employees' work engagement, motivation and more commitment (Karatepe, 2013; Salanova et al., 2005). Karatepe (2013) emphasizes on training, empowerment and rewards system, while Salanova et al. (2005) considered training and autonomy as HRM practices that promote engagement. Earlier, Saks (2006) measured employee engagement by introducing two important practices such as reward and recognition. However, the working environment is also plays as an important determinant of employee engagement as argued by many scholars (Rich et al. 2010; May et al. 2004). The insufficiency of research on the HRM practices led Arrowsmith and Parker (2013) to come to a conclusion that the effects of HRM practices on work engagement remain unclear to HR practitioners.

Budhwar and Debrah (2004) showed that, though predominantly in developed contexts, a remarkable progress in HRM visualized all over the world. Hence, in order to generalize the concept of HRM practices, more studies are required in the developing settings. Recently, Truss et al. (2013) projected that employee engagement depends on how effectively HRM practices are being implemented. Nevertheless, the conceptual and empirical relations among HRM practices, employee engagement, and employees' performance, are not established well (Guest, 2007). The limited researchers, on 
developed context, investigated that how HRM practices affect individual and organizational outcomes through employee engagement(Truss et al., 2013). Therefore, the attempt has been taken to extend the literature on HRM practices, employee engagement, and performance relationships where engagement is expected to play the mediating role in the context of Bangladesh.

RMG industry in Bangladesh has been observed as the life-blood for the economy of the country for more than two decades (Ahmed et al., 2013), boost up economy with more than $80 \%$ of the total exports of the country (Export Promotion Bureau, 2014) and contributing to the GDP by 13\% (Wikipedia, Bangladesh RMG Sector, 2015). RMG industry creates almost 4.00 million employments, who are actually rural poor, in which more than 80 percent of them are female who involved themselves to the economic activities of the country(Export Promotion Bureau, 2014; Mahmud, 2012; Ministry of Labor \& Employment, 2011; Bhattacharya \& Rahman, 2000). Some statistics are presented below in Table-1, so that the importance of RMG industry in Bangladesh can be visualized easily.

Table 1: Growth, Employment and Export of RMG Industry in Bangladesh

\begin{tabular}{|c|c|c|c|c|c|}
\hline Year & $\begin{array}{c}\text { Number of Garment } \\
\text { Factories }\end{array}$ & $\begin{array}{c}\text { Employment } \\
\text { (in Million } \\
\text { Workers) }\end{array}$ & $\begin{array}{c}\text { Export of RMG } \\
\text { (In million US \$) }\end{array}$ & $\begin{array}{c}\text { Total Export of } \\
\text { Bangladesh } \\
\text { (In million US \$) }\end{array}$ & $\begin{array}{c}\text { \% of RMG's to Total } \\
\text { Export }\end{array}$ \\
\hline $2004-2005$ & 4107 & 2.00 & 6417.67 & 8654.52 & 74.15 \\
\hline $2005-2006$ & 4220 & 2.20 & 7900.80 & 10526.16 & 75.06 \\
\hline $2006-2007$ & 4490 & 2.40 & 9211.23 & 12177.86 & 75.64 \\
\hline $2007-2008$ & 4743 & 2.80 & 10699.80 & 14110.80 & 75.83 \\
\hline $2008-2009$ & 4925 & 3.50 & 12347.77 & 15565.19 & 79.33 \\
\hline $2009-2010$ & 5063 & 3.60 & 12496.72 & 16204.65 & 77.12 \\
\hline $2010-2011$ & 5150 & 3.60 & 17914.46 & 22924.38 & 78.15 \\
\hline $2011-2012$ & 5400 & 4.00 & 19089.69 & 24287.66 & 78.60 \\
\hline $2012-2013$ & 5600 & 4.00 & 21515.73 & 27027.36 & 79.61 \\
\hline $2013-2014$ & 4536 & 4.00 & 24491.88 & 30186.62 & 81.13 \\
\hline
\end{tabular}

Source: Bangladesh Garment Manufacturers and Exporters Association (BGMEA) and Export Promotion Bureau (EPB)

The main objective of the study is to review the literatures of HRM practices, employee engagement, and performance to draw relationships among them through the development of a conceptual framework. The study also aims to discover the research gap in the context of RMG industry in Bangladesh so that employees' performance could be improved through the implementation of proper HR practices and employee engagement.

\section{Methodology}

The study has been conducted based on the previous literatures of human resource management practices, employee performance, and employee engagement. The relevant literatures have been reviewed to draw a relationship between human resource management practices and employee performance where employee engagement influences as a mediating factor on this relationship. In addition, the relationship has been appraised in the context of readymade garment industry of Bangladesh on the basis of five aspects of HRM practices such as training and development, compensation, job security, promotion opportunities and relations with supervisor. Secondary data associated with scenario of Bangladesh garment industry, comparative productivity and compensation of the workers is used to discover the insights of the concurrent situations prevail in the RMG industry of Bangladesh. Finally, a conceptual model has been proposed based on the extant literatures. The future direction of the research is also incorporated as well in this study.

\section{Description of Variables}

\subsection{Human Resource Management Practices}

Employees in any organization are the most important asset (Danish \& Usman, 2010). In this context, HRM practices viewed as the activities of organizations dedicated to employee well-being enhancing talents, skills, outputs, and satisfaction (Adedapo, Adewunmi \& Oluwatayo, 2015; McLean \& McLean, 2001). Since employees are inevitable and 
treated as the most vital asset, their feelings and attitudes need to be given high importance (Ghebregiorgis \& Karsten, 2007).Practically, HRM is asset of practices acknowledged to ensure an efficient and effective workforce in the right place to execute operational requirements of the organizations (Jafri, 2013; Swanson \& Holton, 2009). The recent studies discovered that ineffective training, poor payment, lack of job security, work-family clash, unfair performance measurement system, and inappropriate rewards (both financial and non-financial) are widespread common problems in the labour intensive industry (Kong et al., 2010; Kusluvan et al., 2010; Deery, 2008; Poulston, 2008; Watson, 2008). The importance of HRM practices got attention in the context of Western countries and still is continued rather to conduct research in the developing economy (Almhdie and Nyambegera, 2004).

\subsection{Employee Engagement}

The concept of employee engagement, though relatively new but widely accepted among the HRM scholars, has grasped the interest in recent literature over the last two decades (Simon at el., 2015; Sowath et al. 2014;Kim et al., 2012; Rurkkhum \& Bartlett, 2012; Soane et al., 2012; Shuck \& Wollard, 2010). The concept of employee engagement was first imagined by Kahn in 1990 as harnessing of organizational members' selves to their work roles, and during the work, people occupy themselves physically, cognitively, and emotionally. In addition to these, Kahn (1990) supplements three psychological states like meaningfulness, safety, and availability that draw a demarcation between engagement and disengagement at workplace. However, since 2005, the concept engagement was widely discussed among business people, consultant and policy makers that make this concept popular, more specifically, academics confirmed more attention to explore this concept of engagement after 2006 (Welch, 2011).

Employee engagement, not surprising though, is reported to be a continuous turn down worldwide (White, 2006; Bates, 2004). Only 13 percent of employees found engaged around the world in their job (Gallup, 2013). In USA, for example, 52 percent employees are reported disengaged, while 18 percent are actively disengaged in their work. Similarly, 68 percent workers in China are found to be disengaged on their work (Gallup, 2013).Studies reported that the employee engagement levels in Australia, China, Japan, New Zealand, and Singapore were 18\%, 12\%, 9\%, 17\%, and $9 \%$ respectively (Gallup Organization, 2004).

\subsection{Employee Performance}

Employee performance ensures the survival and development of the organization in an extremely competitive environment (Emami et al., 2013). Employee performance is basically the results gained and completion by employees at workplace that keeps up organizational plans though aiming for the expected outcomes (Anitha, 2014). In broad sense, performance is viewed as valued outputs of a production system in the form of goods or services (Swanson and Holton, 2009).

Employee performance combines two dimensions together: in-role and extra-role performance (J. Lee Whittington \&Timothy J. Galpin, 2010). In-role performance denotes attainment of those activities clearly shown for the respective positions to be performed and evaluated in the process of performance appraisal. Extra-role performance signifies the extent where employees go beyond the prescribed job descriptions to the work (Netemeyer and Maxham, 2007). According to Organ (1988), extra-role performance is best expressed by the concept of organizational citizenship behaviour (OCB), where employees spontaneously perform something more beyond the expectation of in-role behaviour.

\section{Relationships among the variables}

\subsection{Training \& Development, Employee Engagement and Employee Performance}

Recent studies showed that employee training enhances the level of their engagement with the job, and it can be used as a weapon to raise engagement (Simon et al. 2015; Albrecht, 2013; Schaufeli \& Salanova, 2010). Some consider training and development as a tool to sharpen performance in the workplace (Lee et al., 2012; Barzegar \& Farjad, 2011).

In the context of Bangladesh, it is anticipated that there is a deficiency of 25 percent skilled workers (Berg, Hedrich, \& Tochtermann, 2012) due to the low education level. Bhattacharya and Rahman (2001) suggested that a constructive policy should undertake to enhance employees' skills and adaptation of new technology as well to boost up the productivity of workers. The comparative productivity (Table 2) statistics of the workers depicted that the performance of the workers in Bangladesh RMG industry is lower than other Asian neighbouring countries. 
Table 2: Comparative Productivity of Garment Workers

\begin{tabular}{|c|c|c|}
\hline SI. No. & Country & Worker's Productivity (Shirts/year) \\
\hline 1 & Pakistan & 3100 \\
\hline 2 & India & 2592 \\
\hline 3 & Bangladesh & 2536 \\
\hline 4 & Sri Lanka & 719 \\
\hline
\end{tabular}

Source: Zohir, S. C. (2000)

A survey on RMG industry revealed that number of un-skilled and semi-skilled workers in the RMG industry of Bangladesh was 20 and 30 percent respectively (Rahman et al. 2008). The percentage of skill workers is 44 and only 6 percent workforces are involved in the professional and management activities. This survey also found that the ratio of skilled workers in large factories ranges from 46 percent to 53 percent, whereas it is 18 percent to 26 percent in the small and medium scale factories. Chowdhury, Ali and Rahman (2005) in their study expressed discontent that unskilled people results poor productivity and thus increase production cost that would be the new challenges in the RMG industry. The skills of labour forces are inevitable (Abdullah 2005a) as the RMG industry is labour intensive (Huda et al., 2007). Therefore, the competitiveness in the RMG sector depends on the productivity of RMG workforce (Abdullah 2009). The above literature established that training and development is a very important HRM practices in the context of RMG industry of Bangladesh and it demand thorough investigation to discover the insight how training and development influence on the employee engagement and ultimately help to increases the performance of the employees.

\subsection{Compensation, Employee Engagement and Employee Performance}

Studies exposed that rewards or compensation have strong influence on employee engagement. For example, Crawford et al. (2014) identified compensation as a key antecedent to employee engagement. Choo et al. (2013) consider it as one of the best predictors of employee engagement; Joshi and Sodhi (2011) argued that employee engagement is the result of better compensation and other monetary benefits. However, majority of the researchers found compensation and employee engagement have significant relationship in the context of western countries (Solomon \& Sridevi, 2010; Sacks, 2006).

The compensation packages given to RMG workers in Bangladesh are the lowest in any industries all over the world. According to Ahamed (2011), Bangladeshi RMG workers receive only 42 percent of an Indian, 50 percent of Nepalese and 33 percent of a Sri Lankan RMG worker receives. It is one of the main hurdles for RMG workers to enhance motivation and performance (Islam Shafiqul, 2014). Several studies (Chowdhury \& Ullah, 2012; Islam \& Zahid, 2012; Uddin, 2008) on the RMG of Bangladesh recognized that the monetary rewards for workers are very poor to meet the livelihood and they are deprived from the benefits prescribed in the Labor Code 2006. Therefore, above literature made a scope to examine how compensation influences on employee engagement and performance in the RMG of Bangladesh.Table-3 is presented the comparative statistics among the South Asian Regional compensation package.

Table 3: Comparative Wages of Garment Workers

\begin{tabular}{|c|l|c|}
\hline SI. No. & Country & Worker's Wages/Month(\$) \\
\hline 1 & Bangladesh & 91.45 \\
\hline 2 & Cambodia & 126.26 \\
\hline 3 & India & 169.67 \\
\hline 4 & Indonesia & 186.64 \\
\hline 5 & Philippines & 233.39 \\
\hline 6 & Vietnam & 254.78 \\
\hline 7 & China & 324.90 \\
\hline 8 & Thailand & 337.12 \\
\hline
\end{tabular}

Source: Center for American Progress, July 2013. 


\subsection{Job Security, Engagement and Performance}

Job security is an important HRM practices for any organizations. Recent studies showed that organizations guaranteed job security can confirm better performance from employees (Islam \& Shazali, 2011; Lee \& Lee, 2007). However, majority of the research findings, directly or indirectly, established the relationship between job security and employee performance. The study of Majumdar (2012) on RMG workers in Bangladesh found that workers' job is not secured, and for this reason the psychological attachment of workers with the factory is also vulnerable. According to Islam and Zahid (2012) about 61 percent workers are not permanent and thus they are passing their days with frightened of losing job. Recent studies (Bhuiyan, 2012; Chowdhury \& Ullah, 2012; Ahamed, 2007) showed that job security of the RMG workers are too low to concentrate over the work physically and mentally results low employee engagement. Job security of garment workers is lower than any other job sectors in Bangladesh (Priyo, 2010; Majumder \& Anwara, 2000). The above discussion assisted to draw a conclusion that job security is one of the significant issues in the RMG industry of Bangladesh that hinder the performance and engagement of the workers.

\subsection{Promotion Opportunity, Engagement and Performance}

Employee engagement gradually amplifies when employee visualized good scope for career growth and advancement (Joshi and Sodhi, 2011). An empirical study on the professional people discovered that employees are highly satisfied with the organization when they go through the reasonable career opportunities (Lim \&Ling, 2012) which in turn, increase the employees' performance (Ahmed \& Uddin, 2012). Promotion opportunity of RMG workers in Bangladesh is very limited and found to work in a same position for a long period of time. Promotion articulated the social status and social status are supposed to the determinants of employees' performance especially in labour-intensive industry (Khan, 2010), thus, promotion opportunities in the RMG industry have an influence on the employees' outputs. Guest (2007) found that promotion and employee performance have positive significant relationship. Therefore, promotion opportunities have an impact on employee engagement and performance in the RMG industry of Bangladesh.

\subsection{Supervisor Relations, Employee Engagement and Performance}

Literatures suggested that managers or supervisors direct relations to their employees are inevitable for employee engagement (Joshi \& Sodhi, 2011; Macey \& Schneider, 2008; Arakawa \& Greenberg, 2007). More importantly, focus should be given on the supervisor-employee relationship if organizations emphasize on employee engagement (Simon et al., 2015). The recent study of Islam (2014) suggested that labour performance and better working conditions are affected by the relationship of employee and employer. In the context of Bangladesh, more specifically for RMG workers, the relationship between workers and supervisor are not congenial, rather continuous misbehaviour of supervisor with their fellow workers is a common phenomenon (Ahmed \& Islam 2014; Ahmed et al., 2013). The above discussion discovered an insight about the supervisory relations with the workers. The supervisor relations and supports have direct relationship to enhance the employees' performance and indirect relationship with the engagement. Therefore, an urge derived to explore the influence of the supervisor relations to employee engagement and performance in the context of RMG workers in Bangladesh.

\section{Conceptual Framework}

A considerable number of earlier researches revealed that HRM practices have a positive impact on the employee performance (Balochi et al. 2010; Qureshi et al., 2010; Khan, 2010). Similarly, HRM practices have been observed as an indicator of work engagement (Karatepe, 2013). Shuck and Rocco (2014) suggested some strategies to increase employee engagement through the implementation of HRM practices. On the other hand, couple of researches (Christian et al., 2011; Leiter \& Bakker, 2010) suggest that high levels of employee engagement augment job performance of the employees.

The proposed conceptual framework of the study presented below: 


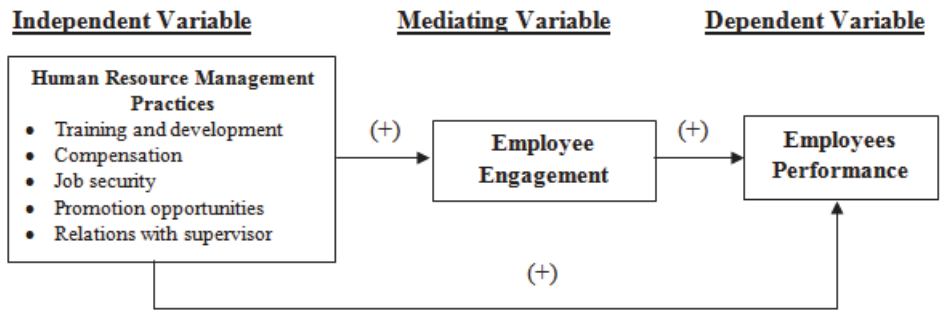

Figure 1: Conceptual Framework

According to Baron and Kenny (1986), support of mediating variable can be undertaken if: independent variables (Human Resource Management Practices) are related to the dependent variable (Employee performance); independent variables (Human Resource Management Practices) are related to the mediating variable (Employee Engagement); and mediating variable (Employee Engagement) is related to the dependent variable (Employee Performance). The earlier literature conform that human resource management practices have significant impact on both employee engagement and employee performance. Therefore, considering employee engagement as mediating variable is logical to conceptualize the relationship between HRM practices and employee performance. But a thorough empirical analysis is essential to generalize this concept because this relationship has not been generally proved earlier.

\section{Discussion}

It can be argued that when HRM practices of any organization are positive and conducive for working environment, employee engagement will be increased and as a result employees' performance will be increased. Previous literatures have pointed out that HRM practices have positive influence on employee performance and employee engagement. Similarly, employee engagement has positive impact on employee performance. Therefore, outstanding employee performance likely to expect when positive influence of HRM practices along with employee engagement is ensued. In the context of developing economy like Bangladesh, this relationship may be important because organizations face a lot of challenges related to HRM practices and employee performance. More specifically, the RMG sector in the country mainly suffer due to lack of appropriate HRM practices related to employees' training, wages/salary, security, promotion and relations with supervisor. As stated earlier, these practices have direct influence on employee engagement and performance. The conceptual links among HRM practices, engagement, and performance are presented below:

- Training and development positively influence on employees' engagement and performance.

- Compensation positively influence on employees' engagement and performance.

- Job security has positive influence on employees' engagement and performance.

- Promotion opportunity has positive impact on employees' engagement and performance.

- Relationship with supervisor has positive impact on employees' engagement and performance.

- Employee engagement positively influence on employee performance.

- Employee engagement mediates the relationship between HRM practices (i.e. training, compensation, security, promotion and relationship) and employee performance.

\section{Conclusion}

The concept 'engagement' is relatively new to generalize and strengthen the relationship between HRM practices and employee performance through existing literatures that deserves a thorough investigation how best employee engagement fine-tune in different contexts, environments and situations to enhance employee performance. Since some debates many researchers argued that good HRM practices increase employee engagement and performance though employees' engagement independently increases employee performance. Nonetheless, the relationships among HRM practices, employee engagement, and performance, are not well established (Guest, 2007; Balain \& Sparrow, 2009). Engagement is a critical issue to HR consultants and practitioners but the dearth of knowledge in existing literatures on employee engagement drives the need for more empirical study. Therefore, this study deserve an empirical research in the context of developing economy like RMG industry in Bangladesh using employee engagement as a mediator to have better understanding of these relationship. 


\section{References}

Abdullah, A. Y. M. (2005a). Labor Productivity and Wastage: The Two Sides of a Coin Bangladeshi RMG Perspective. The AIUB Journal of Business and Economics, 4(2):37-55.

Abdullah, A. Y. M. (2009). The Influence of Work Environment and the Job Satisfaction on the Productivity of the RMG Workers in Bangladesh.Journal of Management, 1 (1): 43-55.

Adedapo, Adewunmi \& Oluwatayo (2015). Employee architect's perception of human resource practices and their job satisfaction.Built Environment Project and Asset Management, 5(1): 89 - 102.

Ahamed, F. (2011). Working conditions in the Bangladesh Readymade Garments Industry: Is Social compliance making a difference? Ph.D Thesis, La Trobe University, Australia.

Ahmed, S. \& Islam, N. (2014).Socioeconomic Factors andLabor Unrest in Ready-Made Garment Industry of Bangladesh. Journal of Education Research and Behavioral Sciences.3(2).

Ahmed, S. \&Uddin, N. (2012).Job Satisfaction of Bankers and its Impact in Banking.ASA University Review.6(2) (11 ${ }^{\text {th }}$ Issue).

Ahmed, S., Raihan, M. Z., \& Islam, N. (2013). Labor Unrest in the Ready-Made Garment Industry of Bangladesh. International Journal of Business and Management.8(15).

Albrecht, S. L. (2010). Handbook of Employee Engagement: Perspectives, Issues, Research, and Practice, Edward Elgar Publishing, Northampton, MA.

Al-Homayan, A. M., Shamsudin, C. Subramaniam\& Islam, R. (2013). Effects of Job Stress and Organizational Support on the Relationship between Job Demand Resources and Nurses' Job Performance in Saudi Public Hospitals, 7(10): 7-19.

Anitha, J. (2014). Determinants of employee engagement and their impact on employee performance. International Journal of Productivity and Performance Management.63(3): 308-323

Arakawa, D. \& Greenberg, M. (2007).Optimistic managers and the influence on productivity and employee engagement in a technology organization: implications for coaching psychologists. International Coaching Psychology Review. 2(1): 78-89.

Arrowsmith, J. \& Parker, J. (2013).The meaning of 'employee engagement' for the values and roles of the HRM function", The International Journal of Human Resource Management.24(14): 2692-2712.

Ashford, S. J., Lee, C., \&Bobko, P. (1989). Content, causes, and consequences of job insecurity: A theory-based measure and substantive test. Academy of Management Journal. 32: 803-829

Balain, S.;\& Sparrow, P. (2009). Engaged to perform A new perspective on employee engagement. Lancaster, UK Lancaster University management school.

Balochi, Q. B., Ali, N., Kiani, T. S., Ahsan, A. \&Mufty, A. (2010). Relationships between human resources practices and perceived employees' performance of bankers in NWFP, Pakistan (an empirical evidence). European Journal of Social Science. 18(2): 210214.

Baron, R. M. \& Kenny, D. A. (1986). The moderator-mediator variable distinction in social psychological research: conceptual, strategic, and statistical considerations. Journal of Personality and Social Psychology. 51(6): 1173-82.

Barzegar, N. \&Farjad, S. (2011). A study on the impact of on the job training courses on the staff performance (a case study). Procedia Social and Behavioral Sciences. 29: 1942-1949.

Bates, S. (2004).Getting engaged. HR Magazine, Vol. 49, pp. 44-51.

Berg, A., Hedrich, S., \&Tochtermann, T. (2012).Bangladesh's readymade garments landscape: The challenges and growth. MaKinsey\& Company.

BGMEA - Bangladesh Garment Manufacturers and Exporters Association (2010)."BGMEA Upbeat on Export Growth". Bizbangladesh.com. Retrieved 2010-10-05.

Bhuiyan, Z. A. (2012). Present Status of Garment workers in Bangladesh: An analysis. IOSR Journal of Business and Management (IOSRJBM). 3(5): 38-44.

Budhwar, P. S. and Debrah, Y. A. (2004).Human Resource Management in Developing Countries, Routledge, London.

Choo,L. S.; Norslah, M.; \& Al-Omari, M. (2013). Organizational Practices and employee engagement: A Case of Malaysian Electronic Manufacturing Firm. Business Strategy Series.14(1).

Chowdhury, M. A. M., Ali, M. M., \&Rahman, R. (2005). WTO, Post MFA Era and the Bangladesh RMG Sector: An Assessment of the performance and challenges. Journal of the Institute of Bankers Bangladesh, 52 (2):87-120.

Chowdhury, N. Ullah, H. (2012)."Present Status of Garment workers in Bangladesh: An analysis", IOSR Journal of Business and Management (IOSRJBM).3(5): 38-44.

Christian, M. S., Garza, A. S. \& Slaughter, J. E. (2011).Work engagement: a quantitative review and test of its relations with and contextual performance. Personnel Psychology.64(1): 89-136.

Crawford, E. R., LePine, J. A. \& Rich, B. L. (2010).Linking job demands and resources to employee engagement and burnout: a theoretical extension and meta-analytic test.Journal of Applied Psychology. Vol. 95, pp. 834-848.

Danish, R. Q. \&Usman, A. (2010).Impact of reward and recognition on job satisfaction and motivation: an empirical study from Pakistan. International Journal of Business and Management. 5(2): 159-167.

Deery, M. (2008).Talent management, work-life balance and retention strategies.International Journal of Contemporary Hospitality Management. 20(7): 792-806.

Emami, F., Omidian, N. B., FazelHashemi S. M. \&MitraPajoumnia (2013). Teacher's Job Attitudes: Comparison and Relationship between Organizational Commitment and Job Involvement among Physical Education Teachers of Iran. Australian Journal of 
Basic and Applied Sciences, 7(1): 7-11

Export Promotion Bureau - EPB (2014). Annual Report 2014. Export Promotion Bureau of Bangladesh.

Gallup (2013). State of the Global Workplace: Employee Engagement Insights for Business Leaders Worldwide, Gallup, Washington, DC.

Gallup Organization (2004), The Gallup Organization, available at: www.gallup.com

Ghebregiorgis, F. \&Karsten, L. (2007). Employees Reactions toHRM and performance in a developing country: Evidence from Eritrea. Personnel Review.36(5).

Guest, D. (2007). HRM and the Worker: Towards a New Psychological Contract. International Journal of Human Resource Management, 12 (7): 1092-1106.

Hossain, G. (2010). Labor turnover in readymade garment (RMG) industry in Bangladesh: The implications of high labour turnover and the affects of high labour turnover for the readymade garment (RMG) industry in Bangladesh: Lambart Academic Publishing.

Hossan, C. G., Sarker M. A. R., \&Afroze, R. (2012). Recent Unrest in the RMG Sector of Bangladesh: Is this an Outcome of Poor Labour Practices? International Journal of Business and Management, 7(3): 206-218.

Huda et al. (2007). HRM Practices and Challenges of Non-government Development Organisation: An Empirical Study on Bangladesh. Journal of Management, 9(1): 35-49.

Islam Md. Shafiqul (2014).Informal Labor Incentives and Firm Performance: A Case Study of RMG Industry in Bangladesh. International Business and Management.8(2): 19-27.

Islam, K. \&Zahid, D. (2012).Socio-economic Deprivation and Garment Worker Movement in Bangladesh: A Sociological Analysis. American Journal of Sociological Research. 2(4): 82-89.

Islam, S. \&Shazali, S. T. (2011).Determinants of manufacturing productivity: pilot study on labor-intensive industries. International Journal of Productivity and Performance Management. 60(6): 567-582.

J. Lee Whittington \& Timothy J. Galpin, (2010).The engagement factor: building a high-commitment organization in a low-commitment world. Journal of Business Strategy. 31(5): $14-24$.

Jafri, H. (2013). HRM practices as a predictor of employee engagement:An Empirical Investigation. ANVESHA The Journal of Management. 6(4).

Joshi, R. J. \&Sodhi, J. S. (2011).Drivers of employee engagement in Indian organizations. The Indian Journal of Industrial Relations. 47(1): 162-182.

Kahn, W. A. (1990). Psychological conditions of personal engagement and disengagement at work. Academy of Management Journal. 33(4): 692-724.

Karatepe, O. M. (2013). High-performance work practices and hotel employee performance: the mediation of work engagement. International Journal of Hospitality Management, Vol. 32, pp. 132-140.

Khan, M. A. (2010). Effects of Human Resource Management Practices on Organisation Performance: An Empirical Study of Oil and Gas Industry in Pakistan. European Journal of Economics, Finance and Administrative Sciences , 24: 158-175.

Kim, W., Kolb, J. A. \& Kim, T. (2012).The relationship between work engagement and performance: a review of empirical literature and a proposed research agenda. Human Resource Development Review. 12(3): 1-29.

Kong, H., Cheung, C. \& Zhang, H. Q. (2010). Career management systems: what are China's state-owned hotels practicing? International Journal of Contemporary Hospitality Management. 22(4): 467-82.

Lee, F. H. \& Lee, F. Z. (2007).The relationships between HRM practices, leadership style, competitive strategy and business performance in Taiwanese Steel Industry. Proceedings of the 13th Asia Pacific Management Conference, Melbourne, pp. 953971.

Lee, H., Boot, W. R., Basak, C., Voss, M. W., Prakash, R. S., Neider, M., Erickson, K. I., Simons, D. J., Fabiani, M., Gratton, G., Low, K. A. \& Kramer A. F. (2012). Performance gains from directed training do not transfer to untrained tasks. ActaPsychologica. 139(1): 146-158.

Leiter, M. P. \& Bakker, A. B. (2010). Work engagement: introduction; in Bakker, A.B. and Leiter, M.P. (Eds), Work engagement: A Handbook of Essential Theory and Research, Psychology Press, Hove, pp. 1-9.

Lim, L. J. W. \& Ling, F. Y. Y. (2012).Human resource practices of contractors that lead to job satisfaction of professional staff. Engineering.Construction and Architectural Management. 19(1): 101-118.

Macey, W. H. \& Schneider, B. (2008). The meaning of employee engagement. Industrial and Organizational Psychology: Perspectives on Science and Practice, Vol. 1, pp. 3-30.

Mahmood, M. (2004). The Institutional Context of Human Resource Management: Case Studies of Multinational Subsidiaries in Bangladesh. Doctoral Dissertation, University of Manchester, UK.

Mahmud, R. B. (2012). Skills development in Bangladesh RMG sector, the News Today, http://www.newstoday.com.bd.

Majumder, P. P. \& Begum, A. (2000). The Gender Imbalances in the Export Oriented Garments Industry in Bangladesh. Policy Research Report On Gender and Development, Working Paper Series No. 12, The World Bank Development Research Group/Poverty Reduction and Economic Management Network..

Majumder, T. H. (2012). Human resource management practices and employees' satisfaction towards private banking sector in Bangladesh. International Review of Management and Marketing. 2(1): 52-58.

May, D. R., Gilson, R. L. \& Harter, L. M. (2004).The psychological conditions of meaningfulness, safety and availability and the engagement of the human spirit at work.Journal of Occupational and Organisational Psychology.77(1).

McLean, G. N. \& McLean, L. (2001). If we can't define HRD in one country, how can we define it in an international context? Human 
Resource Development International. 4(3): 313-326.

Ministry of Labor and Employment (2011). Sixth Five-Year Plan 2011 - 2015. Bangladesh.

Netemeyer, R. G. \&Maxham, J. G. (2007).Employee versus supervisor ratings of performance in the retail customer service sector: differences in predictive validity of customer outcomes. Journal of Retailing.83(1).

Organ, D. (1988). Organizational Citizenship Behavior: The Good Soldier Syndrome, Lexington Books, Lexington, MA.

Poulston, J. (2008), "Hospitality workplace problems and poor training: a close relationship", International Journal of Contemporary Hospitality Management. 20(4): 412-27.

Qureshi, M. T., Ayisha, A., Mohammad, A. K., Rauf, A. S. \& Syed, T. H. (2010). Do human resource management practices have an impact on financial performance of banks? African Journal of Business Management. 4(7): 1281-1288.

Rahman, Mustafizur, Bhattacharya, Debapriya\&Moazzem, KhondakerGolam. (2008). Bangladesh Apparel Sector in Post MFA Era: A Study on the Ongoing Restructuring Process. Dhaka: Centre for Policy Dialogue in association with IFC and SEDF.

Rich, B. L., Lepine, J. A. \& Crawford, E. R. (2010). Job engagement: antecedents and effects on job performance. Academy of Management Journal.53(3).

Saks, A. M. (2006). Antecedents and consequences of employee engagement.Journalof Managerial Psychology.21(7).

Salanova, M., Agut, S. and Peiro, J. M. (2005).Linking organizational resources and work engagement to employee performance and customer loyalty: the mediation of service climate.Journal of Applied psychology. 90(6): 1217-1227.

Shin-Rong, S. H. \& Chin-Wei, C. (2012).Outside director experience, compensation, and performance.Managerial Finance.38(10).

Shuck, B. \& Rocco, T. S. (2014). "Human resource development and employee engagement", in Truss, C., Delbridge, R., Alfes, K., Shantz, A. and Soane, E. (Eds), Employee Engagement in Theory and Practice, Routledge, New York, NY, pp. 116-130.

Shuck, B. \&Wollard, K. K. (2010). Employee engagement and HRD: a seminal review of the foundations. Human Resource Development Review.9(1).

Soane, E., Truss, C., Alfes, K., Shantz, A., Rees, C. \&Gatenby, M. (2012).Development and application of a new measure of employee engagement: the ISA engagement scale .Human Resource Development International.15(5).

Solomon Markos\& M. SandhyaSridevi (2010).Employee Engagement: The Key to Improving Performance. International Journal of Business and Management.5(12): 89-96.

Truss, C., Delbridge, R., Alfes, K., Shantz, A. \&Soane, E. (Eds) (2013). Employee Engagement in Theory and Practice, Routledge, New York, NY, pp. 57-81.

Uddin, S. G. (2008). Wage Productivity and Wage Income Differential in Labour Market: Evidence from RMG Sector in Bangladesh. Asian Social Science.4(12).

Welch, M. (2011). The evolution of the employee engagement concept: communication implications. Corporate Communications: An International Journal. 16(4): 328-346.

White Blessing (2006), Employee Engagement Report, Blessing White, Princeton, NJ.

Wollard, K. K. \& Shuck, B. (2011).Antecedents to employee engagement: a structured review of the literature. Advances in Developing Human Resources.13(4): 429-446.

Zohir, S. C. (2000). Intra-household Relations and Social dynamics among Garment Workers in Dhaka city, Paper presented in the National Seminar on Garment Industry in Bangladesh: Economic and Social dimension. Dhaka 21- 22 January. 